\title{
The Effect of Global Risk Indicators on Developing Country Stock Exchanges: The Case of BRICS-T
}

\author{
Ender BAYKUT ${ }^{\mathrm{a}, *}$, Selver DIYAR ${ }^{\mathrm{b}}$ \\ aAssoc. Prof., Afyon Kocatepe University \\ bMBA Student, Afyon Kocatepe University
}

\begin{abstract}
A B S T R A C T
Global risk factors have great impacts on the economies and financial markets. It is observed that the stock markets of countries are affected by globalization especially in times of global crisis. To this end, CDS, VIX and Credit Ratings have started to be examined recently in order to decrease global risk factors. CDS, VIX, and Credit Ratings were determined as global risk indicators and these variables were used as independent variables to detect the effect on BRICS-T (Brazil, Russia, India, China, South Africa and Turkey) stock market returns. Daily data sets of these variables from 2008 to 2020 were gathered for each country. After preliminary analysis, ARDL model was determined as the best-fitting model for each data set. According to ARDL Bound test approach, except for China, a long-term relationship between variables for the all-remaining (Brazil, Russia, India, South Africa, and Turkey) countries was detected. It means that global risk indicators affect the returns of stock markets in emerging markets.
\end{abstract}

\author{
ART I C LE INFO \\ Keywords: \\ VIX Index, Credit Default Swaps, \\ Global Risk, Emerging Markets. \\ *Corresponding author: \\ ebaykut@aku.edu.tr \\ (Assoc. Prof. Ender BAYKUT ) \\ Article history: \\ Received 14.02.2021 \\ Revised 18.03.2021 \\ Accepted 30 04. 2021 \\ DOI:https://doi.org/10.51410/jcgirm.8.1.7
}

\section{INTRODUCTION}

Countries, as well as, financial markets are affected by global risk factors and leave deep marks on their stock markets and economies. It is common knowledge that risk factors increase, especially in times of crisis. Therefore, it is important to anticipate risk factors and minimize the risk at all times and even more in crises periods. Risk is a factor that can occur at any time and can do great damage. Risk factors have created many risks, especially before and after the 2008 global crisis. At the same time, it can be seen that its effects are great for individual and institutional investors and observed that the effects of some global crises continue for years. As a result, global crises have left much credit, financial, operational, and strategic damages on developing and developed countries. Even if the crisis starts in a country, it can spread all over the world or most of the financial markets. Therefore, risk management must be managed correctly in order to minimize the impact of crises. During times of crises, from the past to the present, great traces were left on the economies when the crises could not be detected in advance and correctly. Risk factors must be analysed well in order to minimize and predict outcomes of the risks of these crises. First, the risk should be at the lowest or reasonable level for investments. 
This is a pre-requisite for investors to make the correct investment. The lower the risk, the more attractive it is for investors to get involved in the financial markets.

There are many global risk indicators for financial markets. Some of them are common and popular but others are not. This paper targets to determine the effects of global risk factors on the developing BRICST (Brazil, Russia, India, China, South Africa, and Turkey) countries' stock markets. To this end, CDS (Credit Default Swaps), VIX and Credit Ratings are used as global risk indicators in this current research.

CDSs create an important place for investors. Investors do not predict a situation such as non-payment when the maturity of their financial instruments is up. Among the risks investors take, this is the most preferred method because it contains the least amount of risk. It can also be said of replacing a country's own credit risk with another country. Credit rating notes are considered as the numerical evaluation of the credit ratings of countries. A decision can be made by looking at the credit rating notes in order to understand a country's investment-note situation. The VIX index is not calculated separately for countries and is evaluated on a grade. The VIX index can be regarded as the most striking issue recently. The VIX index is also known as the fear index. Therefore, the VIX index not only shows short-term changes but also fluctuations in risk perception. Besides, the VIX index is used to detect volatility or how fast prices change during time. In addition, the VIX index is seen as a way of measuring market sentiment, and especially the degree of fear among market participants.

The rest of the paper is organised as follow. In the following section, variables and the theoretical framework of the study are explained one by one. For the second part of the study, a literature review is prepared based on previous studies. After the explanations of methodology and data set, findings and results are summarized. Study ends with conclusion and recommendations.

\section{1. $\quad$ Risk and Global Risk Indicators}

The source of the word risk comes from French. The word originating from the French language, is actually "hazard". When the dictionary meaning of the word "hazard" is examined, it is defined as the danger of injury (Ozbilgin: 2012: 88). Risk can be explained as a threat that prevents events that may or may occur in the future. Also, risk can prevent situations where goals can be achieved. The risk is seen as the possibility of situations that may occur instantly or in the future. Risk can lead to opportunities as well as threats. In addition to being considered as neutralising the negative impact of unexpected events, risk can also mean creating opportunities from negativities with a new perspective over time (Ankara: 2013: 1). Apart from the definition of risk, that of risk management is also important for practitioners. Risk management is the controlling of effects of negative developments on institutions, the management of uncertainties by developing strategies through risk assessment. There are various strategies, namely, transferring the risk to another segment can be a form of risk aversion, mitigating the negative effects of the risk, and accepting some of the consequences of risks. Financial risk management can be described as managing risks through the exchange of financial instruments (Durak: 2009: 4). In this study, risk 
factors are examined from a global perspective and VIX, CDS and credit ratings are determined as global risk indicators. L. Tappan first initiated credit rating agencies between 1837 and 1841 in relation to companies' failure to fulfil their commitments after the collapse of the US economy. In 1909, Moody's companies started to provide ratings such as ' $\mathrm{A}$ ', 'B' and ' $\mathrm{C}$ ' and the first credit ratings were created. Subsequently, the Fitch Company was established. In 1941, Standard and Poor's (S\&P) company was established and these were and have remained the three major companies for credit ratings (Kargi: 2014: 356). In the globalized world, credit rating agencies have increased in importance with the emergence of financial crises. There have been improvements in credit ratings from past to present. It is seen that the importance of credit ratings, which were of little importance at first, has increased in importance recently. These institutions are the institutions that guide investors in the right way, even if they have differences in terms of grading.

Credit default swaps (CDS) are a type of insurance against a particular company's default risk. The company is referred to as the reference asset and it is called the credit default event. It is a contract between two parties called the protection buyer and the protection seller. Under the contract, the protection buyer is compensated for any damage arising from a credit event on a reference instrument. In return, the protection buyer makes periodic payments to the protection seller (The Economic Times: 2020). While credit rating emerged as a tool to express credit risk: Credit Default Swaps (CDS) emerged as an instrument that transfers credit risk and over time has become a credit risk measuring instrument. In this respect, credit rating grades and CDS premiums are important tools that show credit risk (Senol: 2012: 49). Credit default swaps (CDSs) proved to be one of the most successful financial innovations of the 1990s. They are vehicles that provide insurance against a particular company that does not pay its debts. The company is known as the reference asset and the default of the company is known as the credit event. The buyer of the protection makes periodic payments to the protection seller at a predetermined fixed rate each year. Payments continue until the end of the contract's life or a loan event (Hull and White: 2003: 3).

The VIX volatility index is an index that measures the degree of fear found in the Chicago Board Option Exchange Volatility index. Another name for the VIX index is the fear index. The VIX index was established in 1993. Since the VIX index follows the volatility in the markets, it is referred to as the fear index. The increase and amount of expected dividends in the VIX index are calculated using binomial methods. The VIX index was initially calculated on the S\&P 100 index. After 2003, options were followed on the S\&P 500 index. In 1993 the Chicago Board Options Exchange (CBOE) introduced a volatility index based on the prices of index options. This was an implied volatility index based on option prices of the S\&P100 and it was traced back to 1986. Until about 1995 the index was not a good predictor of realized volatility (Brenner, Shu and Zhang: 1989: 63; Jung: 2015: 189). The VIX is an index, like the Dow Jones Industrial Average (DJIA), that is computed on a real-time basis throughout each trading day. The only meaningful difference between the VIX and DJIA is that the VIX measures volatility and the DJIA measures price (Whaley: 2009: 98). 
The VIX Index, CDS premiums and credit ratings are the main variables of this study and the authors examined the impact of these variables on BRICH-T countries based on time series analyse methods. In the following part, literature review of similar studies is summarized.

\section{LITERATURE REVIEW}

The literature review part consists of three parts. These are studies related to credit ratings and its effect on stock markets, VIX Index, and CDS premiums and their impact on financial markets, especially on emerging markets. Firstly, we perused the impression of credit rating scores on stock markets in developing countries. Although credit rating agencies are not of great importance for governments and stock exchanges, credit ratings are accepted as an essential tool for decision-making. It has been determined that credit ratings, particularly in emerging markets, are one of the most crucial parts for institutional investors. Assessment of credit ratings on emerging markets are those mostly subjected to studies (Mihaelajeno, 2015; Afonso et.al. 2012; Fatnassi et.al., 2014; Hull et.al., 2004; Brooks et.al., 2004; Hilscher and Wilson, 2016; Cantor and Packer, 1996; Reisen and Maltzan, 1999; White, 2010; Hooper et.al., 2008; Reinhart, 2002; Kim and Wu, 2011; Aizenman, et.al., 2013; Benmelech and Dlugosz, 2010; Kaminsky and Schmukler, 2002). The findings of these studies address the positive correlation between credit rating and stock market returns. This means that increases in the credit rating create an increase in the stock markets while the opposite is also valid, whereby a decrease in the credit rating create a decrease in stock market returns. The effects of credit ratings on Turkey's stock market is also one hot topic in the literature review, especially for researchers in Turkey. There are a considerable number of studies (Pirgaip, 2017; Tutar et al., 2011; Ovali et al., 2020; Çağlak et al., 2018; Tekin, 2018; Iskenderoglu and Balat, 2018; Y1ldırım et al., 2017; Kargi, 2014; Toraman and Yuruk, 2014) that found that negative movement of credit ratings led to a decrease in stock market returns, especially in Borsa Istanbul Stock Indices. The second risk indicator for the global markets is the VIX index. There are many studies in the literature review to test the effect of the VIX Index on financial markets. Some of these studies focus on the relationship between BIST Indices and VIX Index (Başarır, 2008; Kaya, 2015; Kula and Baykut, 2017; Sarıtas and Nazlioglu, 2019; Bayrakdaroglu and Celik, 2015; Gunay, 2019; Erdogdu and Baykut, 2016; Akcalı et.al., 2019), while some of them dissected the efficacy of VIX Index on emerging markets (Korkmaz and Çevik, 2009; Adjasi et.al., 2008; Mikhaylov, 2018; Oner et.al., 2018; Jayasuriya, 2005; Aizenman and Marion, 1999; Iskenderoglu and Akdag, 2020; Gursoy, 2020; Silva, 2002; Ozdemir, 2020). A significant amount of these studies concluded that the VIX index harms stock markets and economies, especially in emerging markets. Studies about credit default swaps and their effect on financial markets are also popular in the literature review. Kurca et al. (2018), Yenice et al. (2019), Conkar and Vergili (2017), Reyhan and Gazel (2019), Bektur and Malcioglu (2017), Celik and Boztosun (2010), Ozkan and Cakar (2020) examined the CDS and BIST Index from a different perspective. An intensive amount of these studies have found a negative impact of CDS values on BIST Indices. So as with the VIX Index, the CDS rating also has adverse effects on 
Turkey's stock markets. In addition to studies about CDS premium in Turkey, there is a sufficient amount of studies (Arestis et al., 2001; Levina and Zervos, 1998; Demirer et al., 2010; Bologna and Cavallo, 2002; Buberkoku, 1997, Park and Bae, 2004; Kassimatis, 2002; Puliga et al., 2014; Aksoylu and Gormus, 2018; Ericsson et al., 2009; Sahin and Sumer, 2014; Brigo et al., 2012; Abdellahi et al., 2017, Dullmann and Sosinska, 2007; Vurur and Ozen, 2020) that focus on the effect of CDS premiums, especially on emerging markets. Their findings are parallel to the results of studies on BIST Indices.

To test the impact of VIX, CDS and credit ratings on emerging markets, the authors had to choose the best-fitted model to detect long-run relationship between variables. In the next part of the study, the methodology is examined and briefly explained.

\section{METHODOLOGY}

Based on the unit root test result of the variables, we have a different level of unit root for the emerging market (BRICS-T) stock exchanges and VIX, CDS, and Credit ratings. This is why, in order to test the long-run relationship between dependent and independent variable, ARDL model will be applied. The data set of this study consists of stock market indices of BRICS-T (dependent variables) and VIX, CDS, Credit ratings from 2008 to 2020.

\subsection{Autoregressive Distributed Lag Bound Test}

ARDL (Autoregressive Distributed Lag Bound) Test is also known as ARDL Bound Test. The ARDL bound test was developed in 2001 by Muhammad Hashem Pesaran and Sangcheol Shin. This test is used to examine the concept of cointegration with the combination of the series for at least two non-stationary series. Besides, the ARDL bound test method has recently become a more effective and frequently used method compared to the cointegration tests of Johansen (1988), Johansen Juselius (1990) and EngleGranger (1987) (Turna: 2017: 80). ARDL Test has many advantages compared to other cointegration methods. In contrast to other cointegration techniques, ARDL test does not impose a restrictive assumption that all variables under study should be combined in the same order (Şimşek: 2016: 71). ARDL approach is based on the least squares method and unlike classical cointegration analysis, it is not necessary to apply a unit root test beforehand in ARDL analysis (Esen et.al. 2012: 256). ARDL does not have the conditions to be stationary like other cointegration tests. In addition, it aims to express a stationary combination for two non-stationary series. In addition, ARDL has more advantages than other cointegration tests. The ARDL model provides an advantage over other cointegration tests since the variables are not taken into account in the integration degree. It brings about spurious regression in nonstationary time series depending on time series. At the same time, the difference is made in series in order to ensure stability.

When applying ARDL, this is performed in two parts. First, for the ARDL test, the variables of the subject and model are examined, and categorised as long term or short term. Flexibility will be decided by using the ARDL test in the test results. At the same time, under the condition that there is a cointegration relationship, long and short runs are tested among variables. In order to determine lag 
lengths, long and short term relationships between dependent and independent variables are determined. To determine lag lengths, AIC and SHC (Schwartz) selection criteria of dependent and independent variables are used. On the other hand, the smallest criterion among the lag lengths constitutes the lag length of the model (Baykut: 2020: 101). The first unconstrained error correction model defined for the ARDL test by Pesaran and Shin is given below:

$$
\Delta \gamma_{t=a_{0}}+\sum_{i=1}^{m} a_{1 i} \Delta \gamma_{t-1}+\sum_{i=0}^{m} a_{2 i} \Delta M_{t-i}+\sum_{i=0}^{m} a_{3 i} \Delta E_{t-i}+a_{4} \gamma_{t-1}+a_{5} M_{t-1}+a_{6} E_{t-1}+\mu_{t}
$$

In order to determine that there is an ARDL test cointegration relationship, the coefficients of the first period lags of dependent and independent variables are tested collectively by applying the F-statistics test (Wald test) to determine significance. H0 hypotheses expressing the absence of cointegration between variables of the ARDL test are formed. These H0 hypotheses are as follows:

$$
\mathrm{H}_{0}: \mathrm{a}_{1}=\mathrm{a}_{2}=\ldots=\mathrm{a}_{\mathrm{k}}=0 \longrightarrow \text { No cointegration hypothesis }
$$

ARDL test is the alternative H0 hypothesis expressing the presence of cointegration in variables is as follows:

$$
\mathrm{H}_{1}: \mathrm{a}_{1} \neq \mathrm{a}_{2} \neq \ldots \ldots \ldots \ldots \ldots \ldots \ldots \mathrm{a}_{\mathrm{k}} \neq 0 \longrightarrow \text { Cointegration exists alternative hypothesis }
$$

The ARDL technique is preferred when results are I(0) and I(1), or when there were both combinations dealing with variables integrated in different order. However, if the situation is I(2) for the ARDL model, this technique becomes disabled. One also notes that when using the ARDL test technique, there is only one long-term relationship between basic variables of small size. If the basic forms have a long-term relationship, this is determined by the F-statistics (Wold Test). The distribution of F-statistics is not standard regardless of whether the variables in the system are I (0) and I(1) (Nkoro and Uko: 2016: 81). Although there are no requirements for ARDL testing, unit root testing is recommended. In order to avoid misapplication, prediction and interpretation based on forecasting and policy stance, it is necessary to investigate the necessary conditions that reveal the ARDL co-integration technique. If the conditions are complied with, it may lead to inconsistent and unrealistic estimates with the erroneous determination of the model and its effect on the estimation and policy (Nkoro and Uko: 2016: 63). ARDL bound test can be formulated as follow (Baykut: 2020: 101):

$$
\Delta Y_{t}=\alpha_{0}+\sum_{i=1}^{m} \alpha_{1 i} \Delta Y_{t-\bar{i}}+\sum_{i=0}^{m} \alpha_{2 i} \Delta X_{t-\bar{i}}+\alpha_{3} X_{t-\bar{i}}+\alpha_{4} X_{t-1}+e_{t}
$$

In the ARDL test, after the long-term is determined, the optimum length structure should be selected using standard criteria such as Swartz Bayesian (SBC) or Akaike Information (AIC). Therefore, the next step is to determine the long-run and short-run coefficients in the models. The long-term formula for the ARDL test is as follows (Özçalık: 2014: 367):

$Y_{t}=\alpha_{0}+\sum_{i=1}^{m} \alpha_{1 i \bar{i}} Y_{t-\bar{i}}+\sum_{i=0}^{m} \alpha_{2 i} M_{t-\bar{i}}+\sum_{i=0}^{m} \alpha_{3 i} E_{t-\bar{i}}+\mu_{t}$ 
Error correction term is used in ARDL short run model. The short run dynamic model can be presented as follows (Özçalık: 2014: 367):

$$
\Delta Y_{t}=\alpha_{0}+\sum_{i=1}^{m} \alpha_{2 \bar{i}} \Delta Y_{t-\bar{i}}+\sum_{i=0}^{m} \alpha_{3 \bar{i}} \Delta M_{t-\bar{i}}+\sum_{i=0}^{m} \alpha_{4 \bar{i}} \Delta E_{t-\bar{i}}+\alpha_{1} E C_{t-\bar{i}}+\mu_{t}
$$

In the ARDL error and short-run test, the ARDL long model formulation with Y dependent variables and two independent variables ( $\mathrm{E}$ and $\mathrm{M}$ ) can be predicted by the above formulas by econometrics and statistics programs. The EC in the ARDL test formula shows the Error Correction Model. ARDL Error Correction Model aims to show how soon shocks that occur due to independent variables will stabilize in the long term.

\section{ANALYZE AND FINDINGS}

In the analyse part of the paper, the first part consists of descriptive statistic and unit root test applied to detect structure of the data set. The paper aims to expose the long-run relationship between global risk indicators and emerging markets stock market. After determining whether the data sets are stable or not, the long-term relations of the countries were examined by applying the time series model. To this end, the first section of the analyses is focussed to generate descriptive statistic. The descriptive statistic of the data set is provided in Table 1.

Table 1: Descriptive statistics BRICS-T Countries

\begin{tabular}{|c|c|c|c|c|c|c|c|}
\hline Country & Variable & Mean & Min. & Max. & Standard Dev. & Jarque Bera & Observation \\
\hline \multirow{3}{*}{ Turkey } & VIX & 19.16711 & 9.14 & 82.69 & 8.55 & 7030 & 2893 \\
\hline & CDS & 1823.72 & 110 & 3209.22 & 104.57 & 1241.15 & 2613 \\
\hline & BIST-100 & 817.37 & 445.85 & 1479.91 & 195.96 & 95.44 & 2613 \\
\hline \multirow{3}{*}{ Brazil } & VIX & 19.16711 & 9.14 & 82.69 & 8.55 & 7030 & 2893 \\
\hline & CDS & 193.5874 & 87.97 & 521.36 & 84.83 & 1290 & 2893 \\
\hline & Bovespa & 66466.59 & 36234.69 & 119527.6 & 18312.48 & 479.25 & 2893 \\
\hline \multirow{3}{*}{ Russia } & VIX & 19.16711 & 9.14 & 82.69 & 8.55 & 7030 & 2893 \\
\hline & CDS & 200.81 & 54.64 & 781.26 & 112.62 & 8683.22 & 2710 \\
\hline & RTSI & 1823.72 & 553.62 & 3209.22 & 547.70 & 148.94 & 2710 \\
\hline \multirow{3}{*}{ India } & VIX & 19.16711 & 9.14 & 82.69 & 8.55 & 7030 & 2893 \\
\hline & CDS & 109.81 & 95.07 & 271.49 & 37.33 & 120.23 & 926 \\
\hline & Nifty-50 & 9994.25 & 6970.60 & 12362.30 & 1496.01 & 77.66 & 926 \\
\hline \multirow{3}{*}{ China } & VIX & 19.16711 & 9.14 & 82.69 & 8.55 & 7030 & 2893 \\
\hline & CDS & 81.99 & 27.68 & 256.69 & 33.52 & 2408.23 & 2542 \\
\hline & SSEC & 3272.14 & 1817.72 & 5353.75 & 679.06 & 39.15 & 2542 \\
\hline \multirow{3}{*}{ South Africa } & VIX & 19.16711 & 9.14 & 82.69 & 8.55 & 7030 & 2893 \\
\hline & CDS & 201.6 & 103.75 & 507.93 & 65.14 & 2258.91 & 2779 \\
\hline & JTOPI & 39555.13 & 16230.19 & 55484.28 & 10436.59 & 267.37 & 2779 \\
\hline
\end{tabular}


After obtaining the descriptive statistics of the series, a high volatility was observed in the data set in the relevant period. It should also be taken into account that there were global financial crisis and corona virus effects in this period. Even if the number of data of the countries is different, there is an increasing momentum in the stock market returns of developing countries. This situation arises from the graphs of the stock market data of each country index. In addition, VIX index and CDS premiums generally follow a stable course, except in crisis periods. High volatility is observed in the data for these two variables only in times of crisis. After the descriptive statistics were obtained, the unit root tests of the series were performed and reported in Table 2.

Table 2: Unit Root Test Results

\begin{tabular}{|c|c|c|c|c|}
\hline Country & Variable & Level & First Difference & Decision \\
\hline \multirow{3}{*}{ Turkey } & VIX & $\begin{array}{c}-5.742118 \\
(0.0000)\end{array}$ & - & $I(0)$ \\
\hline & CDS & $\begin{array}{c}-3.437911 \\
(0.0467)^{* * *}\end{array}$ & - & $I(0)$ \\
\hline & BIST-100 & $\begin{array}{c}-2.394224 \\
(0.3824)\end{array}$ & $\begin{array}{c}-33.44413 \\
(0.0000)^{* * *}\end{array}$ & $I(1)$ \\
\hline \multirow{3}{*}{ Brazil } & VIX & $\begin{array}{c}-5.742118 \\
(0.0000)\end{array}$ & - & $I(0)$ \\
\hline & CDS & $\begin{array}{c}-2.630122 \\
(0.2667)\end{array}$ & $\begin{array}{c}-25.04225 \\
(0.0000)^{* * *}\end{array}$ & $I(1)$ \\
\hline & BOVESPA & $\begin{array}{c}-1.590885 \\
(0.7967)\end{array}$ & $\begin{array}{c}-36.00386 \\
(0.0000)^{* * *}\end{array}$ & $I(1)$ \\
\hline \multirow{3}{*}{ Russia } & VIX & $\begin{array}{c}-5.742118 \\
(0.0000)\end{array}$ & - & $I(0)$ \\
\hline & CDS & $\begin{array}{c}-4.412383 \\
(0.0021)\end{array}$ & - & $I(0)$ \\
\hline & RTSI & $\begin{array}{c}-3.119988 \\
(0.1017)\end{array}$ & $\begin{array}{c}-51.99437 \\
(0.0000)\end{array}$ & $I(1)$ \\
\hline \multirow{3}{*}{ India } & VIX & $\begin{array}{c}-5.742118 \\
(0.0000)\end{array}$ & - & $I(0)$ \\
\hline & CDS & $\begin{array}{c}-3.317598 \\
(0.0640)\end{array}$ & $\begin{array}{c}-8.005912 \\
(0.0000)^{* * *}\end{array}$ & $I(1)$ \\
\hline & NIFTY-50 & $\begin{array}{c}-1.974654 \\
(0.6139)\end{array}$ & $\begin{array}{c}-29.14221 \\
(0.0000)^{* * *}\end{array}$ & $I(1)$ \\
\hline \multirow{3}{*}{ China } & VIX & $\begin{array}{c}-5.742118 \\
(0.0000)\end{array}$ & - & $I(0)$ \\
\hline & CDS & $\begin{array}{c}-4.050393 \\
(0.0012)^{* * *}\end{array}$ & - & $I(0)$ \\
\hline & SSEC & $\begin{array}{l}3.076236 \\
(0.1122)\end{array}$ & $\begin{array}{c}-49.47439 \\
(0.0000)^{* * *}\end{array}$ & $I(1)$ \\
\hline South Africa & VIX & -5.742118 & - & $I(0)$ \\
\hline
\end{tabular}




\begin{tabular}{|c|c|c|c|c|}
\hline \multirow{2}{*}{ CDS } & $(0.0000)$ & - & $I(0)$ \\
\cline { 2 - 5 } & \multirow{2}{*}{ JTOPI } & $\begin{array}{c}-4.493923 \\
(0.0015) * * *\end{array}$ & -25.04225 & I(1) \\
\cline { 2 - 5 } & & -3.353917 & $(0.0000)^{* * *}$ & \\
\hline
\end{tabular}

*** Significant at $5 \%$.

As a result of the unit root test analysis, different levels of unit root for each data set were obtained. VIX index is the same for all countries and calculated globally. Since the unit root result of different orders was obtained for each variable, it was decided to use the ARDL model to determine the long-term relationship between the series. Because of the different unit root level of variables, the ARDL model was deemed the best model for the assessment of relationship between stock exchanges and global risk indicators. For this purpose, the ARDL model was applied for all country data and the best fitted ARDL models are shown in Table 3.

Table 3: Model Selection

\begin{tabular}{|c|c|c|c|c|c|}
\hline Country & Stock Exchange & VIX & CDS & Best Fitted Model & Selected Model \\
\hline Brazil & $I(1)$ & $I(0)$ & $I(1)$ & $A R D L$ & ARDL $(2,3,4)$ \\
\hline South Africa & I(1) & $I(0)$ & $I(0)$ & $A R D L$ & ARDL $(2,2,3)$ \\
\hline China & $I(1)$ & $I(0)$ & $I(0)$ & $A R D L$ & ARDL $(2,3,4)$ \\
\hline India & I(1) & $I(0)$ & $I(1)$ & $A R D L$ & ARDL $(2,1,3)$ \\
\hline Russia & $I(1)$ & $I(0)$ & $I(0)$ & $A R D L$ & ARDL $(2,1,3)$ \\
\hline Turkey & I(1) & $I(0)$ & $I(0)$ & $A R D L$ & ARDL $(4,4,4)$ \\
\hline
\end{tabular}

In order to determine the fitted ARDL model, firstly, the suitable lag length must be detected. To detect appropriate lag length, the VAR model was generated, applied, and summarized in Table 4. In the last column of Table 4, the most suitable ARDL model lag length for each country is given. After determining the most suitable lag length, the ARDL Bound test application phase was started and the results are shown in Table 4. In the ARDL Bound test approach, in order to have a long-term relationship between variables, the detected $\mathrm{f}$ statistic must be higher than the upper bound value. If the $\mathrm{f}$ statistic is lower than the lower bound, there is no long-term relationship, and if the f statistic is between the lower and upper bound, no definite relationship can be mentioned. The $\mathrm{f}$ statistic between the lower and upper bounds is expressed as the grey area and is generally not reported. While reporting, calculations should be made according to the significance levels of $1 \%, 2.5 \%, 5 \%$ and $10 \%$. Based on these rules, results are summarized in the following table.

109 | P a g e | Journal of Corporate Governance, Insurance, and Risk Management | 2021, VOL. 8, Series. 1 
Table 4: Bound Test Results

\begin{tabular}{|c|c|c|c|c|c|c|c|c|c|c|}
\hline \multirow[b]{2}{*}{ Country } & \multirow[b]{2}{*}{$\mathrm{k}$} & \multirow[b]{2}{*}{$\begin{array}{c}f- \\
\text { statistic }\end{array}$} & \multicolumn{2}{|c|}{$\begin{array}{c}\text { Critical values at the } \\
\text { significance level in } \\
1 \%\end{array}$} & \multicolumn{2}{|c|}{$\begin{array}{c}\text { Critical values at the } \\
\text { significance level in } \\
2.5 \%\end{array}$} & \multicolumn{2}{|c|}{$\begin{array}{c}\text { Critical values at the } \\
\text { significance level in } \\
5 \%\end{array}$} & \multicolumn{2}{|c|}{$\begin{array}{c}\text { Critical values at the } \\
\text { significance level in } \\
10 \%\end{array}$} \\
\hline & & & $\begin{array}{l}\text { Lower } \\
\text { bound }\end{array}$ & $\begin{array}{l}\text { Upper } \\
\text { bound }\end{array}$ & $\begin{array}{l}\text { Lower } \\
\text { bound }\end{array}$ & $\begin{array}{l}\text { Upper } \\
\text { bound }\end{array}$ & $\begin{array}{l}\text { Lower } \\
\text { bound }\end{array}$ & $\begin{array}{l}\text { Upper } \\
\text { bound }\end{array}$ & $\begin{array}{l}\text { Lower } \\
\text { bound }\end{array}$ & $\begin{array}{l}\text { Upper } \\
\text { bound }\end{array}$ \\
\hline Turkey & 2 & 7.55 & 4.99 & 5.85 & 4.37 & 5.16 & 3.88 & 4.61 & 3.38 & 4.02 \\
\hline Brazil & 2 & 5.42 & 4.99 & 5.85 & 4.37 & 5.16 & 3.88 & 4.61 & 3.38 & 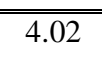 \\
\hline Russia & 2 & 4.74 & 4.13 & 5 & 3.55 & 4.38 & 3.1 & 3.87 & 2.63 & 3.35 \\
\hline China & 2 & 3.93 & 5.15 & 6.36 & 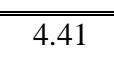 & 5.52 & 3.79 & 4.85 & 3.17 & 4.14 \\
\hline S. Africa & 2 & 9.59 & 4.13 & 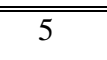 & 3.55 & 4.38 & 3.1 & 3.87 & 2.63 & 3.35 \\
\hline India & 2 & 9.81 & 4.99 & 5.85 & 4.37 & 5.16 & $\begin{array}{l}.88 \\
\end{array}$ & 4.61 & 3.38 & 4.02 \\
\hline
\end{tabular}

According to the results obtained after the application of the ARDL model, there is a long-term relationship between the variables in all countries except China. 5\% significance level is considered sufficient to determine the relationship between variables in social sciences. From this perspective, statistically significant relationships were found in most of the established ARDL models starting from the $2.5 \%$ significance level. F statistic values obtained in the model established for Turkey is significant at the $1 \%$ significance level. This f-statistic value was determined to be higher than the upper limit value at all levels. The same is true for the model established for South Africa and India. In the ARDL model established for the data set of South Africa and India, the long-term relationship between variables is valid at $1 \%$ significance level. On the other hand, in the analyses for Brazil and Russia, no statistically significant relationship was found at the $1 \%$ significance level. Just after $1 \%$ significance level, $\mathrm{f}$ statistic is significant for $2.5 \%, 5 \%$ and $10 \%$ level. Whereas, there is no statistically significant relationship detected for China based on ARDL Bound test. It means that, VIX, CDS and stock exchange variables are not cointegrated in the long-run. So, CDS and VIX index values are not a meaningful decision criteria for the China stock market. For the rest (Turkey, Brazil, Russia, South Africa and India) CDS and VIX index numbers must be taken into consideration for the investment decisions relating to the stock markets.

\section{CONCLUSION}

Through globalization, the borders surrounding various countries have disappeared. The crisis that occurs in one country, thanks to globalization, is spreading quickly among other countries. Hence, any crisis can be said to go beyond any geographical barriers. Risks increase due to developments in markets and economies between countries. Accordingly, given the problems that occur in the markets in this globalized world, risk management and risk protection methods have had to be addressed in all countries. Although a crisis might start in one country, this could cause havoc across the whole world. 
The 2008 crisis can be cited as the most important example. Although the 2008 crisis emerged in the developed country, it affected the economies of the whole world from one day. This crisis caused great damage to the economies of the whole world. Countries that want to avoid certain crisis and risks have tried to implement measures to protect countries' economies. They aimed to keep the economies of the country under control through indices such as CDS, Credit rating and VIX. Despite the fact that the credit rating method is the most commonly used method, one has to consider that it carries a little risk. However, CDSs also carry little risk and protect the investors from said risks. For this reason, CDS are the most traded products among loan derivatives and are very popular in the liquid market. The VIX index is seen as the subject that has been followed and researched recently. Countries try to avoid risks by following the VIX index, that is, the fear index.

In this study, the effects of global risk indicators on developing country stock markets were examined. To this end, BRICS-T (Brazil, Russia, India, China, South Africa and Turkey) countries are determined as an emerging market for the current research. The data set of the study covers a period between 2008 and 2020. This period contains both global financial crises and the coronavirus pandemic. Both of them affected the stock markets very negatively. To determine the relationship of global risk indicators and stock markets, ARDL model was determined as the best fitted model for each stock market just after applying unit root test. Based on the ARDL model, it was determined that 5 out of 6 countries showed that there was a significant relationship between the variables. Except for China, there is a statistically significant relationship between CDS premiums, VIX index and stock market returns of emerging markets. It means that, VIX and CDS premiums significantly affect the returns of Turkey, Brazil, Russia, South Africa and India stock market indices. Therefore, investors should take into account VIX and CDS premiums when investing in these countries and especially in their securities. These outputs are consistent with the previous studies by (Buberkoku, 1997; Levina and Zervos, 1998; Arestis et al., 2001; Bologna and Cavallo, 2002; Park and Bae, 2004; Dullmann and Sosinska, 2007; Ericsson et al., 2009; Demirer et al., 2010; Brigo et al., 2012; Sahin and Sumer, 2014; Puliga et al., 2014; Kaya, 2015; Erdogdu and Baykut, 2016; Kula and Baykut, 2017; Abdellahi et al., 2017; Aksoylu and Gormus, 2018; Sarıtas and Nazlioglu, 2019; Gunay, 2019; Akcalı et.al., 2019; Vurur and Ozen, 2020) in the literature. For further studies, is the authors recommend to carry out research on MSCI Emerging Markets Index countries by applying not only CDS and VIX Index but also MOVE Index and JP Morgan Volatility Index to detect the effects of risk indicators on emerging markets stock indices.

\section{Acknowledgement}

This study, generated from the ongoing master thesis (the same name as the article) at the graduate school of social science of Afyon Kocatepe University.

111 | P a g e | Journal of Corporate Governance, Insurance, and Risk Management | 2021, VOL. 8, Series. 1 


\section{REFERENCES}

Abdellahi, S. A., Mashkani, A. J., and Hosseini, S. H. (2017). “The Effect of Credit Risk, Market Risk, and Liquidity Risk on Financial Performance Indicators of the Listed Banks On Tehran Stock Exchange”. American J. Finance and Accounting, 5(1), 20-30

Adjasi, C., Harvey, S. K., and Agyapong, D. (2008). "Effect of Exchange Rate Volatility on the Ghana Stock Exchange”. African Journal of Accounting, Economics, Finance and Banking Research, 3(3), 28-47.

Afonso, A., Furceri, D., and Gomes, P. (2012). "Sovereign Credit Ratings and Financial Markets Linkages: Application to European Data”. Journal of International Money and Finance, 31(3), 606-638. Doi:10.1016/J.Jimonfin.2012.01.016

Aizenman, J., and Marion, N. (1999). "Volatility and Investment: Interpreting Evidence from Developing Countries”. Economica. The London School of Economics and Political Science, 66, 157-79.

Aizenman, J., Binici, M., and Hutchison, M. M. (2013). “Credit Ratings and the Pricing of Sovereign Debt during the Euro Crisis”. Oxford Review of Economic Policy. Doi:10.1093/Oxrep/Grt036

Akçali, B. Y., Mollaahmetoğlu, E., and Altay, E. (2019, Aralık). "Borsa Istanbul ve Küresel Piyasa Göstergeleri Arasındaki Volatilite Etkileşiminin DCC-GARCH Yöntemi ile Analizi”. Eskişehir Osmangazi Üniversitesi IIBF Dergisi, 14(3), 597 - 614.

Aksoylu , E., and Görmüş , Ş. (2018). "Gelişmekte Olan Ülkelerde Ülke Riski Göstergesi Olarak Kredi Temerrüt Swaplari: Asimetrik Nedensellik Yöntemi”. The International Journal of Economic and Social Research, 14(1), 15-33.

Arestis, P., Demetriades, P. O., and Luintel, K. B. (2001).” Financial Development and Economic Growth: The Role of Stock Markets”. Journal of Money, Credit and Banking, 33(1), 16-41. Http://Www.Jstor.Org/Stable/2673870

Başarir, Ç. (2018). "Korku Endeksi (VIX) Ile BIST-100 Arasindaki Ilişki: Frekans Alani Nedensellik Analizi”. Işletme Fakültesi Dergisi, 19(2), 177-191. Doi:10.24889/Ifede.468802

Baykut , E. (2020). “Kredi Temerrüt Swapları ve Gelişen Piyasalar”. Ekin Yayınevi.

Bayraktaroğlu, H., and Çelik, I. (2015). “Kurumsal Yönetim Uygulamalarinin Getiri Oynakliği Üzerine Etkisi: Borsa Istanbul'da Bir Araştirma.” Journal Of Economics And Administrative Sciences, XVII(1), 97-108. Doi:10.5578/Jeas.9801

Bologna, P., and Cavallo, L. (2002). "Does The Introduction Of Stock Index Futures Evectively Reduce Stock Market Volatility? Is the `Futures Evect’ Immediate? Evidence from the Italian Stock Exchange Using GARCH”. Applied Financial Economics, 12(3), 183-192. Doi:10.1080/0960310011008808

Brenner, M., \& Galai, D. (1989). "New financial instruments for hedging changes in volatility" .Financial Analysts Journal, 45(4), 61-65.Retrieved from https://www.jstor.org 
Brigo, D., Capponi, A., and Pallavicini, A. (2012). “Arbitrage-Free Bilateral Counterparty Risk Valuation under Collateralization and Application to Credit Default Swaps”. Mathematical Finance, 0(0), 1-22. Doi:10.1111/J.1467-9965.2012.00520.X

Brooks, R., Faff, R. W., Hillier, D., and Hillier, J. (2004). “The National Market Impact of Sovereign Rating Changes”. Journal of Banking and Finance, 28, 233-250. Doi:10.1016/S03784266(02)00406-5

Büberkökü, Ö. (1997). “Hisse Senedi Fiyatlari ile Döviz Kurlari Arasindaki Ilişkinin Incelenmesi: Gelişmiş ve Gelişmekte Olan Ülkelerden Kanitlar”. IMKB Dergisi, 13(52), 1-18.

Çağlak, E., Küçükşahin, H., and Kahraman, K. K. (2018). "Uluslararası Kredi Derecelendirme Kuruluşlarının Kredi Not Kararlarının Türkiye Finansal Piyasalarına Etkisi: Borsa Istanbul Sektör Endeksleri Üzerine Bir Uygulam”a. Ömer Halisdemir Üniversitesi Iktisadi Ve Idari Bilimler Fakültesi Dergisi, 11(4), 41-63. Doi:10.25287/Ohuiibf.459153

Cantor, R., and Packer, F. (1996). “Determinants and Impact Of Sovereign Credit Ratings”. Frbny Economic Policy Review, 37-54.

Çonkar, M. K., and Vergili, G. (2017).” Kredi Temerrüt Swaplari Ile Döviz Kurlari Arasindaki Ilişki: Türkiye için Amprik Bir Analiz”. Ömer Halisdemir Üniversitesi Iktisadi ve Idari Bilimler Fakültesi Dergisi, 10(4), 59-66. Doi:10.25287/Ohuiibf.310704

Demirer, R., Kutan, A. M., and Chen, C.-D. (2010). “Do Investors Herd In Emerging Stock Markets?: Evidence From The Taiwanese Market”. Journal of Economic Behaviour and Organization, 76, 283-295. Doi:10.1016/J.Jebo.2010.06.013

Ankara (2013). “Risk ve Risk Yönetimi Olgusu”. Ankara. Açı Ders Ankara: Https://Acikders.Ankara.Edu.Tr/Pluginfile.Php/102169/Mod_Resource/Content/0/Ders\%20notu \%2013.Pdf

Dullmann , K., and Sosinska, A. (2007). “Credit Default Swap Prices as Risk Indicators Of Listed German Banks”. Fin Mkts Portfolio Mgmt, 21, 269-292. Doi:10.1007/S11408-007-0053-7

Erdoğdu, H. and Baykut, E., (2016). “BIST Banka Endeksi’nin (XBANK) VIX ve Move Endeksleri Ile Ilişkisinin Analizi”. Bankacılar Dergisi (98), 57-72.

Ericsson, J., Jacobs, K., and Oviedo, R. (2009). “The Determinants of Credit Default Swap Premia”. Journal of Financial and Quantitative Analysis, 44(1), 109-132. Doi:10.1017/S0022109009090061

Esen, E., Yildirim, S., and Kostakoğlu, S. F. (2012). "Feldstein-Horioka Hipotezinin Türkiye Ekonomisi için Sınanması: ARDL Modeli Uygulaması”. Eskişehir Osmangazi Üniversitesi IIBF Dergisi, 7(1), 251-267.

Fatnassi, I., Ftiti, Z., and Hasnaoui, H. (2014). “Stock Market Reactions to Sovereign Credit Rating Changes: Evidence from Four European Countries”. The Journal of Applied Business Research, 30(3), 953-958. Doi:10.19030/Jabr.V30i3.8579

113 | P a g e | Journal of Corporate Governance, Insurance, and Risk Management | 2021, VOL. 8, Series. 1 
Gunay, S. (2019). “An Analysis Through Credit Default Swap, Asset Swap And Zero-Volatility Spreads Coup Attempt And BIST 100 Volatility”. Borsa Istanbul Review, 19(2), 158-170. Doi:10.1016/J.Bir.2018.11.001

Gursoy, S. (2020). "Investigation of the Relationship between VIX Index and Brics Countries Stock Markets: An Econometric Applicatio”n. Makü-Uyg. Bil. Derg., 4(2), 397-413.

Hilscher, J., and Wilson, M. (2017). “Credit Ratings And Credit Risk: Is One Measure Enough?” Management Science, 63(10), 3414-3437. Doi:10.1287/Mnsc.2016.2514

Hooper, V., Hume, T., and Kim, S. J. (2008). “Sovereign Rating Changes—Do They Provide New Information For Stock Markets? Economic Systems”, 32(2), 142-166. Doi:10.1016/J.Ecosys.2007.05.002

Hull, J., and White, A. D. (2003). "The Valuation of Credit Default Swap Options”. The Journal of Derivatives, 10(3), 1-28. Doi:10.3905/Jod.2003.319200

Hull, J., Predescu, M., and White, A. (2004). “The Relationship Between Credit Default Swap Spreads, Bond Yields, And Credit Rating Announcements”. Journal of Banking and Finance, 28, 27892811. Doi:10.1016/J.Jbankfin.2004.06.010

Iskenderoglu, O., and Akdag, S. (2020). "Comparison Of The Effect of VIX Fear Index on Stock Exchange Indices of Developed on Stock Exchange Indices of Developed”. South East European Journal of Economics and Business, 15(1), 105-121. Doi:10.2478/Jeb-2020-0009

Iskenderoğlu, O., and Balat, A. (2018). "Ülke Kredi Notlarının CDS Primleri Üzerindeki Etkisi: BRICS Ülkeleri ve Türkiye Üzerine Bir Uygulama”. BDDK Bankacılık ve Finansal Piyasalar, 12(2), 4764.

Jayasuriya, S. (2005). "Stock Market Liberalization and Volatility In The Presence Of Favourable Market Characteristics and Institutions”. Emerging Markets Review, 6, 170-191. Doi:10.1016/J.Ememar.2005.03.001

Kargi, B. (2014). “A Study on International Credit Rating Agencies and Turkey’s Credit Rate (19982013)”. The Journal of Academic Social Science Studies (24), 351-370. Doi:10.9761/Jasss2243

Kassimatis, K. (2002). "Financial Liberalization and Stock Market Volatility In Selected Developing Countries.” Applied Financial Economics, 12(6), 389-394. Doi:10.1080/09603100010001937.

Kaya, E. (2015). "Borsa Istanbul (BIST) 100 Endeksi ile Zımni Volatilite (VIX) Endeksi Arasındaki Eş-Bütünleşme ve Granger Nedensellik”. KMU Sosyal Ve Ekonomik Araştırmalar Dergisi, 17(28), 1-6.

Kim, S.-J., and Wu, E. (2011). "International Bank Flows to Emerging Markets: Influence Of Sovereign Credit Ratings And Their Regional Spill over Effects”. The Journal of Financial Research, Xxxiv (2), 331-364.

Kirca, M., Boz , F. C., and Yildiz, Ü. (2018). “Enflasyon Ve Iktisadi Büyümenin Kredi Risk Primi (CDS) Üzerindeki Etkisi: BRICS Ülkeleri ve Türkiye Örneği”. ICOAEF'18 IV. International Conference On Applied, (S. 406-418). Kuşadası/Turkey. 
Korkmaz, T., and Çevik, E. I. (2009). "Zımni Volatilite Endeksinden Geliflmekte Olan Piyasalara Yönelik Volatilite Yayılma Etkisi”. BDDK Bankacılık ve Finansal Piyasalar, 3(2), 87-105.

Kula, V., and Baykut, E. (2017). "Borsa Istanbul Kurumsal Yönetim Endeksi (XKURY) Ile Korku Endeksi (Chicago Board Options Exchange Volatility Index-VIX) Arasindaki Ilişkinin Analizi”. Journal of Economics and Administrative Sciences, 19(2), 27-37. Doi:10.5578/Jeas.63964

Levine, R., and Zervos , S. (1998). “Capital Control Liberalization and Stock Market Development”. World Development, 26(7), 1169-1183.

Mihaelajeno, M. (. (2015). “Credit Rating Agency Performance In Terms of Profit”. Procedia Economics and Finance, 30, 631 - 642. Doi:10.1016/S2212-5671(15)01276-9

Mikhaylov, A. Y. (2018). "Volatility Spill over Effect between Stock And Exchange Rate In Oil Exporting Countries”. International Journal of Energy Economics And Policy, 8(3), 321-326.

Nkoro, E., and Uko, A. K. (2016). “Autoregressive Distributed Lag (ARDL) Cointegration Technique: Application and Interpretation”. Journal of Statistical and Econometric Methods, 5(4), 63-91.

Öner, H., Içellioğlu, C. Ş., and Öner, S. (2018). "Volatilite Endeksi (VIX) ile Gelişmekte Olan Ülke Hisse Senedi Piyasası Endeksleri Arasındaki Engel-Grangereş-Bütünleşme ve Granger Nedensellik Analizi”. Finansal Araştırmalar ve Çalışmalar Dergisi, 10(18), 110-124. Doi:10.14784/Marufacd.460670

Ovali, S. (2014). “Ülke Kredi Notu Değerlendirme Kriterleri Açisindan Türkiye: AB ile Karşilaştirmali Analiz”. Uluslararası Yönetim Iktisat ve Işletme Dergisi, 10(23), 53-80. Doi:10.17130/Ijmeb.2014.10.23.671

Özbilgin, I. G. (2012). “Risk ve Risk Çeşitleri”. Bilişim Dergisi, 86-93. Http://Www.Bilisimdergisi.Org.Tr/S145/Pdf/86-93.Pdf.

Özçalik, M. (2014). “Türkiye'de Para Talebi Fonksiyonu: Bir ARDL Yaklaşimi”. The Journal of Social and Economic Research, 14(27), 359-373.

Özdemir, L . (2020). "VIX Endeksinin BİST30 Endeks ve BISST30 Vadeli İşlem Getirisi Volatilitelerine Etkisinin EGARCH Modeli İle Karşılaştırılması” . Journal of Yaşar University , 15 (59) , 534543 . DOI: 10.19168/jyasar.699550

Özkan, O., and Çakar, R. (2020). "Gelişmiş ve Gelişmekte Olan Piyasalarda Ortalama-Varyans ve Tek Endeks Optimizasyon Yöntemlerinin Karşılaştırılması”. Cankırı Karatekin University Journal of the Faculty of Economics and Administrative Sciences, 10(1), 63-79. Doi:10.18074/Ckuiibfd.441098.

Park, S., and Bae, Z.-T. (2004). "New Venture Strategies in A Developing Country: Identifying A Typology and Examining Growth Patterns Through Case Studies”. Journal of Business Venturing, 19, 81 - 105. Doi:10.1016/S0883-9026(02)00110-6

Pirgaip, B. (2017). “Impacts of Credit Rating Changes on Borsa Istanbul (BIST) Equity Market”. Ege Academic Review, 17(3), 351 / 368. Doi:10.21121/Eab.2017328402 
Puliga, M., Caldarelli, G., and Battiston, S. (2014). "Credit Default Swaps Networks and Systemic Risk”. Scientific Reports, 4 (6822), 1-8. Doi:10.1038/Srep06822

Reinhart, C. M. (2002). "Default, Currency Crisis and Sovering Credit Ratings”. The World Bank Economic Review, 16(2), 151-170.

Reisen, H., and Maltzan, J. V. (1999). “Boom, Bust, and Sovereign Ratings”. International Finance, 2(2), 273-293.

Reyhan, Y., and Gazel, S. (2020). "CDS Primleri Arasındaki Etkileşim: Gelişmekte Olan Ülkeler Üzerine Bir Inceleme.” Finans Politik and Ekonomik Yorumlar, 181-215.

Şahin, C., and Sümer, K. K. (2014). "Gelişmiş ve Gelişmekte Olan Ülke Borsalari ile Türk Borsasi Arasindaki Etkileşime Yönelik Bir Inceleme”. Trakya Üniversitesi Sosyal Bilimler Dergisi, 16(2), 315-338.

Saritaş, H., and Nazlioğlu, E. H. (2019). "Korku Endeksi, Hisse Senedi piyasasi ve Döviz Kuru Ilişkisi: Türkiye Için Ampirik Bir Analiz”. Academic Review of Economics and Administrative Sciences, 12(4), 542-551. Doi:10.25287/Ohuiibf.538592

Şenol, Z. (2021). “Kredi Temerrüt Takaslari (CDS) ve Kredi Derecelendirme (Credit Default Swaps (CDS) and Credit Rating)”. Güncel Ekonomi ve Yönetim Bilimleri Araştirmalari, 49-90.

Silva, G. F. (2002). "The Impact of Financial System Development on Business Cycles Volatility: Cross-Country Evidence”. Journal of Macroeconomics, 24, 233-253.

Şimşek, T. (2016). “The Investigation Of Relationship Between Energy Consumption And Economic Growth By ARDL Bound Test In Turkey”. Journal of International Management, Educational and Economics Perspectives, 4(1), 69-78.

Tekin, I. Ç. (2018). “Kredi Derecelendirme Kuruluşlarının Öngöremedikleri Krizler ve Iflaslar”. Selçuk Üniversitesi Sosyal Bilimler Meslek Yüksekokulu Dergisi, 19(41), 181-205.

Toraman, C., and Yürük, M. F. (2014). "Kredi Derecelendirme Kuruluşlari ve Finansal Krizlere Etkileri”. BEU. SBE. Dergi, 3(1), 127-154. Https://Dergipark.Org.Tr/Tr/Download/ArticleFile/41780

Turna, Y. (2017). “Türkiye’de Ekonomik Büyüme ile Fiziki Sermaye, Beşeri Sermaye ve Enerji Tüketimi Arasindaki Ilişki: NARDL Yaklaşimi”. Pamukkale Üniversitesi Sosyal Bilimler Enstitüsü (Yüksek Lisans Tezi).

Tutar, E., Tutar, F., and Eren, M. V. (2011). "Uluslararasi Kredi Derecelendirme Kuruluşlarinin Rolü, Güvenirlilik Açisindan Sorgulanmasi ve Türkiye”. Akademik Bakiş Dergisi (25). Https://www.Akademikbakis.Org

Vurur, N. S. and Ozen, E. (2020). “Covid-19 Salgininin Cds Primleri İle Borsa Endeksleri Arasindaki İlişki Üzerine Etkileri: Başlica Avrupa Endeksleri İçin Bir Uygulama”. Ekonomi, Politika \& Finans Araştırmaları Dergisi, 2020, 5(Özel Sayı): 97-114

Whaley, R. E. (2009). “Understanding the VIX”. The Journal of Portfolio Management Spring 2009, 35 (3) 98-105; DOI: https://doi.org/10.3905/JPM.2009.35.3.098. 
White, L. J. (2010). “Markets The Credit Rating Agencies”. Journal of Economic Perspectives, 24(2), 211-226. Doi:10.1257/Jep.24.2.211

Yenice, S., Çelik, Ş., and Çevik, Y. E. (2019). "Kamu Finansmani, Finansal Piyasalar ve Kredi Temerrüt Riski: Türkiye ve BRICS Ülkeleri Uygulamas”i. C.Ü. Iktisadi ve Idari Bilimler Dergisi, 20(1), $226-240$.

Yildirim, H. H., Araz, B., Tatan, D., Çalişkan, D., Yildiz, C., and Aydemir, Ö. (2017). "Kredi Derecelendirme Kuruluşlarindan S\&P, Moody’s ve FITCH'in Türkiye için Yapmiş Olduklari Not Açiklamalarinin Endeksler Üzerine Etkisi: Borsa Istanbul Örneği” 2012-201. 